\title{
Pathogenicity and Management of Olpidium bornovanus, a Root Pathogen of Melons
}

\author{
M. E. Stanghellini, D. M. Mathews, and I. J. Misaghi, Department of Plant Pathology and Microbiology, Univer- \\ sity of California, Riverside 92521
}

\author{
ABSTRACT \\ Stanghellini, M. E., Mathews, D. M., and Misaghi, I. J. 2010. Pathogenicity and management of \\ Olpidium bornovanus, a root pathogen of melons. Plant Dis. 94:163-166.
}

Greenhouse studies document, for the first time, that Olpidium bornovanus, an obligate, holocarpic, root-inhabiting zoosporic fungus heretofore regarded as a nonpathogenic parasite, is a root pathogen. Significant browning of the roots and reductions in shoot and root growth were recorded within 28 days following inoculation of melons with the fungus. Amending the recirculating nutrient solution with either a nonionic surfactant (Agral 90) or a strobilurin fungicide (azoxystrobin) resulted in efficacious management of the disease caused by the fungus.

Vine decline of melons (Cucumis melo L.), a disease characterized by a sudden and field-wide collapse of mature fruitbearing plants 1 to 2 weeks before harvest, has historically been attributed to Monosporascus cannonballus, a soilborne, rootinfecting ascomycete $(6,15,19)$. However, Melon necrotic spot virus (MNSV), which is well documented as a destructive viral disease of greenhouse-grown melons $(1,5,7,11,14,26)$, as well as field-grown melons $(12,13,24)$, has recently been reported as a probable cause of vine decline of melons in the field in Guatemala (8). This virus is seedborne and transmitted (in a vector-assisted manner; 4) by Olpidium bornovanus (Sahtiyanci) Karling (=Olpidium radicale), an obligate, soilborne, rootinhabiting, zoosporic fungus (3,25). According to Campbell and Sim (3), there are three host-specific strains (i.e., melon, cucumber, and squash) of $O$. bornovanus. Our preliminary studies showed that the melon strain of $O$. bornovanus is common in soil samples collected from commercial melon fields (4 from Arizona and 10 from California) with a history of vine decline caused by $M$. cannonballus. The fungus was isolated from soil using melon seedlings as bait (8). The presence of the fungus and the absence of the virus (which has not been reported to occur in the United States since its original discovery [9] in a greenhouse in Riverside, CA in

Corresponding author: M. E. Stanghellini

E-mail: michael.stanghellini@ucr.edu

Accepted for publication 28 October 2009.

doi:10.1094/PDIS-94-2-0163

(C) 2010 The American Phytopathological Society
1979) raised questions regarding the pathogenicity of $O$. bornovanus. The latter fungus, in addition to two other species of the genus that are associated with plant roots (i.e., $O$. brassicae and $O$. virulentus), is commonly regarded as a nonpathogenic obligate parasite $(10,17,23)$. However, a possible pathological effect was suggested from a greenhouse study following the observation of a brown discoloration of melon roots colonized by O. bornovanus (3).

The primary objective of this study was to assess the pathogenic capabilities of $O$. bornovanus on melons. Additionally, the efficacy of a surfactant and a fungicide on control of this root-inhabiting, zoosporic fungus was examined. A preliminary report has been published (20).

\section{MATERIALS AND METHODS}

Pathogen and host. All experiments were conducted using cantaloupe ( $\mathrm{Cucu}$ mis melo L. cv. Caravelle) as a host. A single sporangium isolate of $O$. bornovanus (IP-1) recovered from soil from a commercial melon field (Imperial Valley, CA) was maintained on cantaloupe seedlings (hereafter referred to as the inoculum-source-plant [ISP]) growing in vermiculite in a growth chamber.

Cantaloupe seeds were surface sterilized by soaking in $0.6 \%$ commercial sodium hypochlorite for $3 \mathrm{~min}$, rinsed in distilled water for $1 \mathrm{~min}$, and germinated aseptically on $1.5 \%$ water agar in petri plates at $30^{\circ} \mathrm{C}$. The seedlings ( 3 days old) were then transplanted into rockwool cubes $(1.5 \times$ $1.5 \times 1.5 \mathrm{~cm}$ ) and grown for 10 days in a growth chamber at $30^{\circ} \mathrm{C}$ with a $12-\mathrm{h}$ photoperiod. They were then transplanted into vermiculite in $11 \times 11 \times 12 \mathrm{~cm}$ plastic pots and relocated to a temperature-controlled
(20 to $35^{\circ} \mathrm{C}$ ) greenhouse containing 18 drip-irrigated recirculating hydroponic units (Jetstream, American Agritech, Tempe, AZ) (Fig. 1). Each drip-irrigated unit consisted of two fiberglass troughs (each $110 \times 21.5 \times 12 \mathrm{~cm})$ connected to a common reservoir containing 25 liters of aerated nutrient solution, which was distributed continuously to each plant via 7.2 liters/h emitters. Four potted plants were placed in each trough, eight plants per unit (Fig. 1A). Eight days after placement of potted plants in troughs, $0.5 \mathrm{~g}$ (fresh weight) of cantaloupe roots colonized by $O$. bornovanus was excised from the ISP and placed in the nutrient solution in reservoirs of appropriate treatments. Treatments included four noninoculated and four inoculated hydroponic units. Root colonization by $O$. bornovanus was assessed as follows: at 2-day intervals after inoculation, a small section of the potting substrate was excised from one potted plant from each replication of the inoculated treatments. Roots were extracted from the potting medium and examined microscopically $(\times 40)$ for the presence of sporangia in epidermal cells. The shoot portions of two plants randomly selected from each treatment replication $(N=8)$ were excised at the surface of the potting medium at 14, 21, and 28 days after inoculation, and their fresh shoot weights were recorded (Fig. 1B). Additionally, the root systems of two plants from each treatment replication were removed from the pots, washed, and visually assessed for root discoloration. At the final harvest date (i.e., 28 days after inoculation), ten 1-cm-long root segments ( 0.2 to $0.4 \mathrm{~mm}$ in diameter) from each plant were randomly selected and examined microscopically $(\times 40)$ for the presence of sporangia and resting spores of $O$. bornovanus, and their numbers were recorded. The remaining root system of each plant was blotted dry and fresh weights recorded. Data were subjected to analysis of variance (ANOVA). Means were compared by Fisher's protected least significant difference (LSD) at $P=0.05$. The experiment was repeated two more times over a 12 -month period, and results from a single representative experiment were chosen for presentation. Additionally, the experiment was repeated once with another single sporangium iso- 
late of $O$. bornovanus recovered from a commercial melon field soil in Arizona (HQ-1).

Chemical control studies. Cantaloupe seedlings were reared and grown in the greenhouse as described above. There were four treatments with two replications per treatment, and the experiment was repeated once. Treatments included noninoculated hydroponic units, inoculated units, and inoculated units in which the nutrient solution in the reservoir was amended with either a nonionic surfactant (Agral 90, ICI, United Plant Protection Division, UK) or a systemic azoxystrobin fungicide (Quadris, 2.08 SC, Syngenta). The surfactant was chosen because it had previously been documented to control this zoosporic fungus on hydroponically grown cucumbers (25) and zoosporic rootinfecting oomycetes $(18,21,22)$. The surfactant was applied at the following rate: $20 \mu \mathrm{g}$ a.i./ml of the nutrient solution in the reservoir 3 days prior to inoculation and then $20 \mu \mathrm{g}$ a.i./ml at 7-day intervals. The fungicide was added to the reservoir at the following rate: $10 \mu \mathrm{g}$ a.i./ml 3 days prior to inoculation and then repeated at 7-day intervals. At 28 days after inoculation, the shoot and root systems of all plants in each treatment replication were harvested and data recorded as described above. Data were subjected to analysis of variance (ANOVA). Means were compared by Fisher's protected least significant difference (LSD) at $P=0.05$. The experiment was conducted two times, and results from a single representative experiment were chosen for presentation.

Virus screening. Leaves and roots from randomly selected cantaloupe seedlings and mature experimental plants were harvested throughout the above trials and used to test for the presence of plant viruses by several methods. They were specifically tested for the presence of MNSV and $\mathrm{Cu}$ cumber mosaic virus (CMV) by doubleantibody sandwich, direct enzyme-linked immunosorbent assay (DAS-direct ELISA) (Agdia, Elkhart, IN). These tissues were
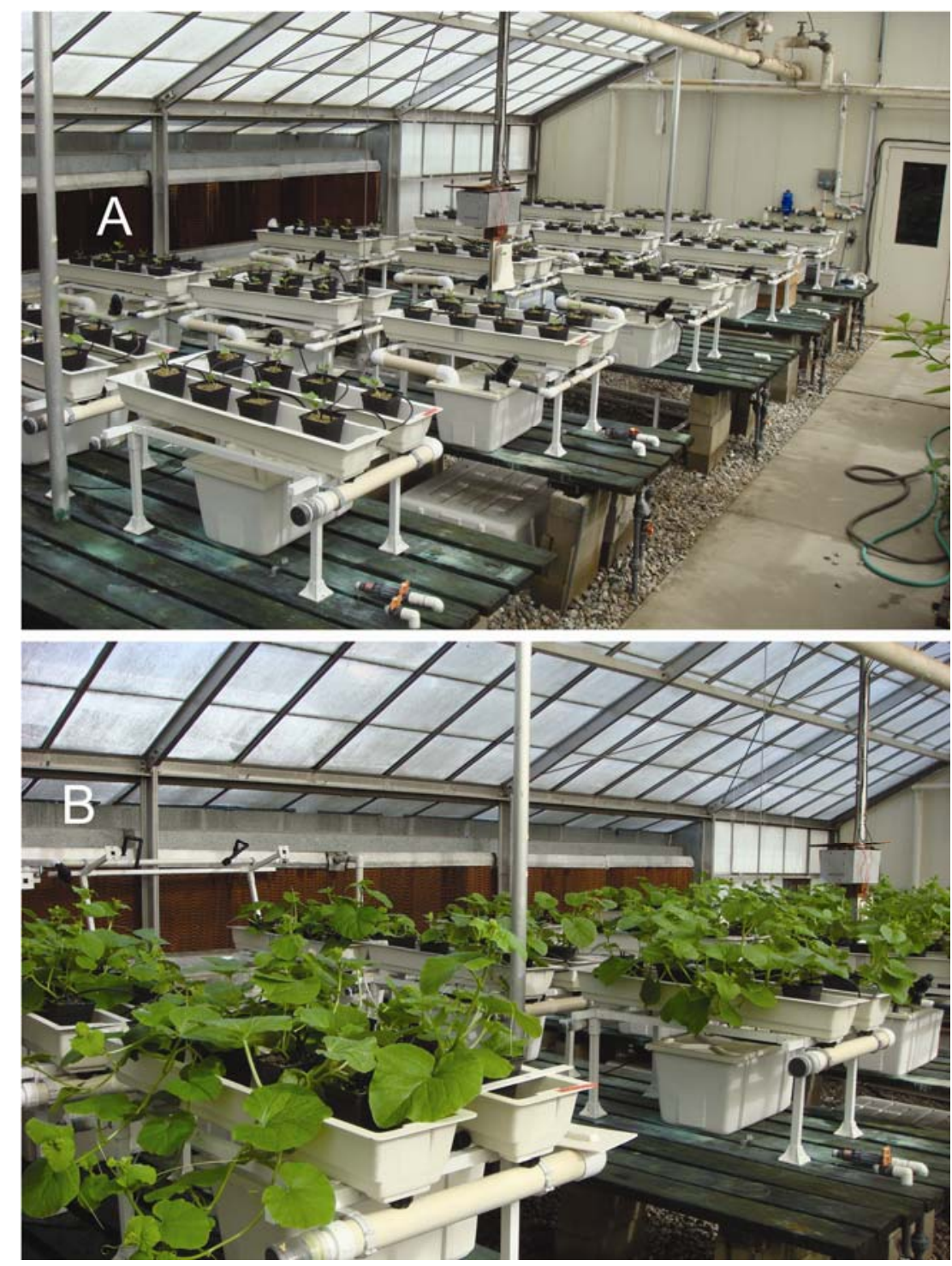

Fig. 1. Potted cantaloupe plants in recirculating hydroponic units in a temperature-controlled greenhouse A, 5 days prior to and $\mathbf{B}, 21$ days after inoculation with Olpidium bornovanus.

also used for double-stranded RNA (dsRNA) extraction and analysis by $6 \%$ polyacrylamide gel electrophoresis (16). Finally, the cantaloupe samples were ground in $0.1 \mathrm{M}$ potassium phosphate buffer, $\mathrm{pH} 7.2(1: 2 \mathrm{wt} / \mathrm{vol})$, and the extracts were used to inoculate Chenopodium quinoa, Nicotiana glutinosa, Gomphrena globosa, and cantaloupe plants. Plants were observed for 18 days for the development of symptoms.

\section{RESULTS}

Pathogenicity studies. Sporangia of $O$. bornovanus were first observed in epidermal cells of roots of melon plants 6 days after artificial infestation of the recirculating nutrient solution. At that time, approximately $5 \%$ of the roots examined were colonized, and the mean number of sporangia per millimeter of root $(0.2$ to 0.4 $\mathrm{mm}$ in diameter) was 0.04 (range $=0$ to 28). Significant reductions (38 to 58\%) in fresh shoot weights in inoculated treatments, relative to the noninoculated treatments, were recorded at all sampling dates (Fig. 2A). Roots of cantaloupe plants in inoculated treatments appeared slightly discolored (tan coloration) 14 days after inoculation. By 28 days following inoculation, the root systems of all inoculated plants were brown (Fig. 3), and all roots examined were extensively colonized by O. bornovanus. Both sporangia and resting spores were microscopically observed in colonized root cells (Fig. 4), and the mean number of propagules of $O$. bornovanus per millimeter of root was 215 (range $=41$

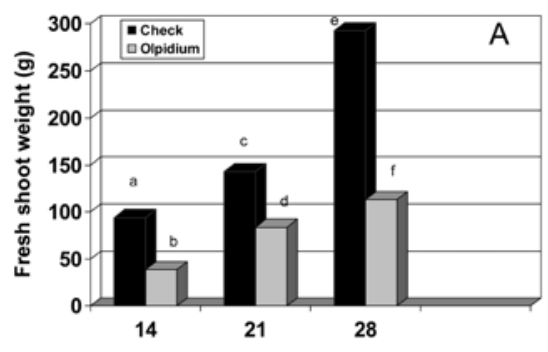

Days after inoculation

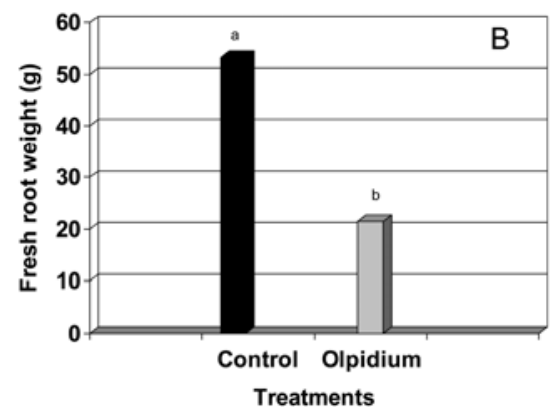

Fig. 2. Effect of Olpidium bornovanus on $\mathbf{A}$, fresh shoot weight of cantaloupe plants at various time intervals after inoculation and $\mathbf{B}$, fresh root weight 28 days after inoculation. Each column is the mean weight from eight plants, and different letters indicate significant differences according to Fisher's protected least significant difference $(P=0.05)$. 
to 632). A significant reduction (40\%) in fresh root weights of inoculated plants, relative to the noninoculated ones, was recorded (Fig. 2B).

No sporangia or resting spores were microscopically observed in roots of noninoculated plants. Repeat experiments with both the IP-1 and HQ-1 isolates of $O$. bornovanus gave similar results (data not shown).

Chemical control studies. Amending the nutrient solution with either the nonionic surfactant or the strobilurin fungicide resulted in complete control of the pathogen. No sporangia or resting spores of $O$. bornovanus were observed in roots of inoculated-chemically treated plants. Fresh weights of roots of the latter plants at the end of the experiment were statistically similar to or greater than root weights of noninoculated plants. In contrast, root and shoot fresh weights of inoculated plants were significantly reduced (22 and $45 \%$, respectively) relative to the noninoculated and inoculated-chemically treated plants (Fig. 5A and B). Roots of inoculated melon plants were brown in color, and almost all epidermal root cells contained either sporangia or resting spores of $O$. bornovanus.

Virus detection. All plants tested were negative for MNSV and CMV by DASdirect ELISA (data not shown). No dsRNA segments were observed on gels used to analyze extracts from experimental cantaloupe plants. No symptoms developed on inoculated leaves or in systemic leaves of indicator hosts after inoculation with cantaloupe extracts from the various experiments.

\section{DISCUSSION}

While $O$. bornovanus is well documented as the vector of MNSV $(2,9,14)$, our data indicate that this fungus is also a virulent pathogen capable of causing extensive browning of the roots and growth reductions in infected cantaloupe plants. We ruled out the possibility of viral infections causing any of these symptoms during this study, either due to MNSV or other

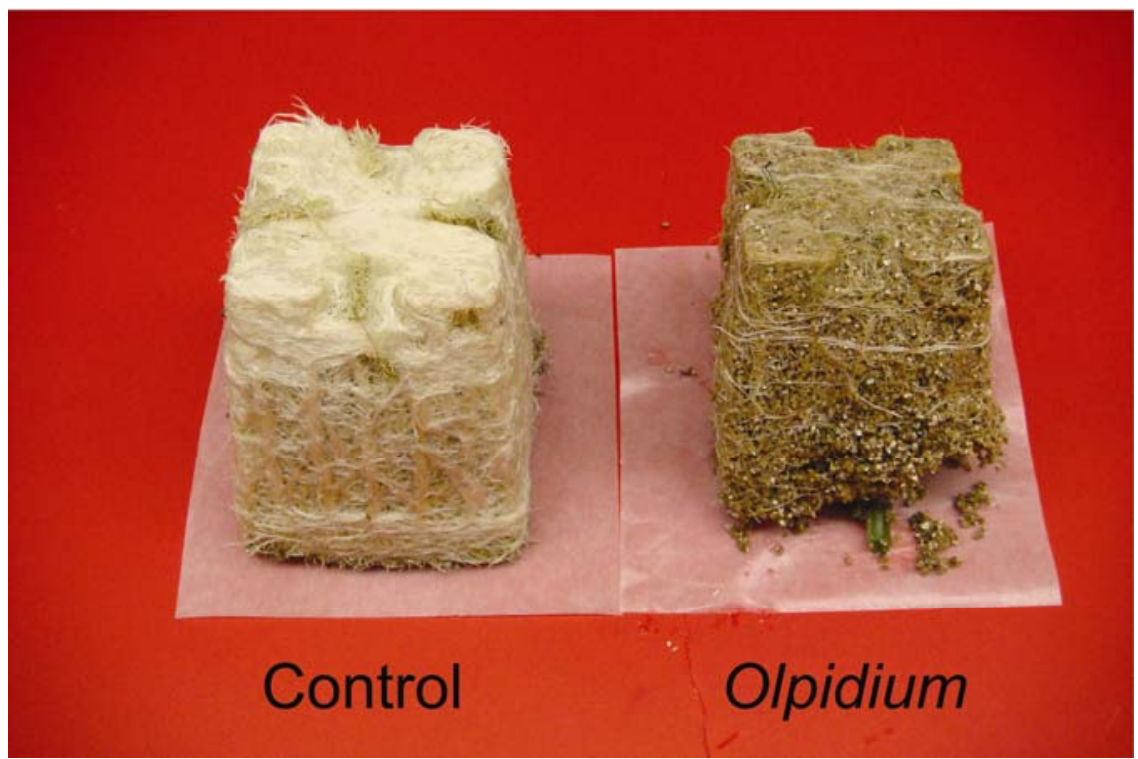

Fig. 3. Comparison of the root system of a healthy and an Olpidium bornovanus-colonized plant 28 days after inoculation. common melon-infecting viruses. Based upon these findings, the extent of crop loss due to $O$. bornovanus in cantaloupe plants grown commercially in greenhouse environments $(1,5,7,11,14,26)$, which was previously attributed primarily, if not solely, to the virus, needs to be reassessed. Our studies also indicate that amending the recirculating nutrient solution with either azoxystrobin (Quadris) or Agral 90 (which confirms an earlier study [25] on its efficacy in control of the cucumber strain of the fungus) provided excellent management of the disease on greenhouse grown melons caused by the cantaloupe strain. However, the role of $O$. bornovanus as a
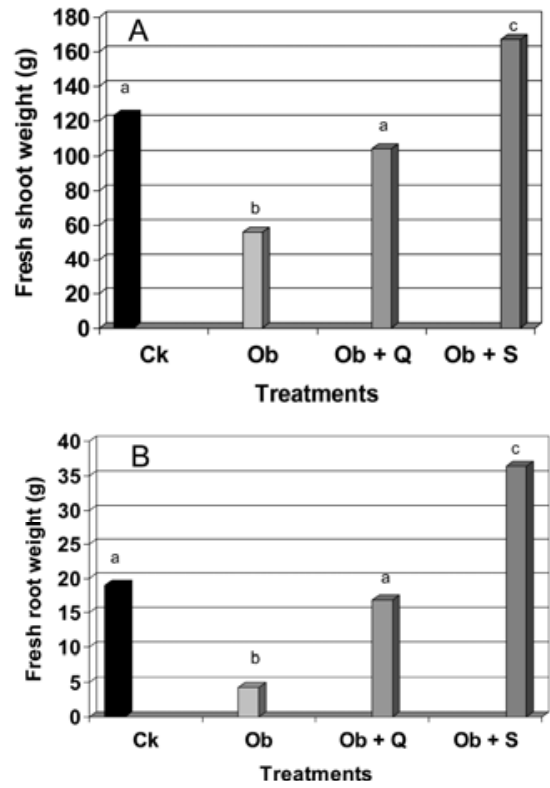

Fig. 5. Effect of chemical amendments to the recirculating nutrient solution on $\mathbf{A}$, fresh shoot weight and $\mathbf{B}$, fresh root weight of hydroponically grown cantaloupe plants 28 days after inoculation with Olpidium bornovanus $(\mathrm{Ob})$. $\mathrm{Ck}$ = control, $\mathrm{S}=$ a nonionic surfactant (Agral 90), and $\mathrm{Q}=$ a strobilurin fungicide (Quadris). Each column is the mean weight from 16 plants, and different letters indicate significant differences according to Fisher's protected least significant difference $(P=0.05)$.

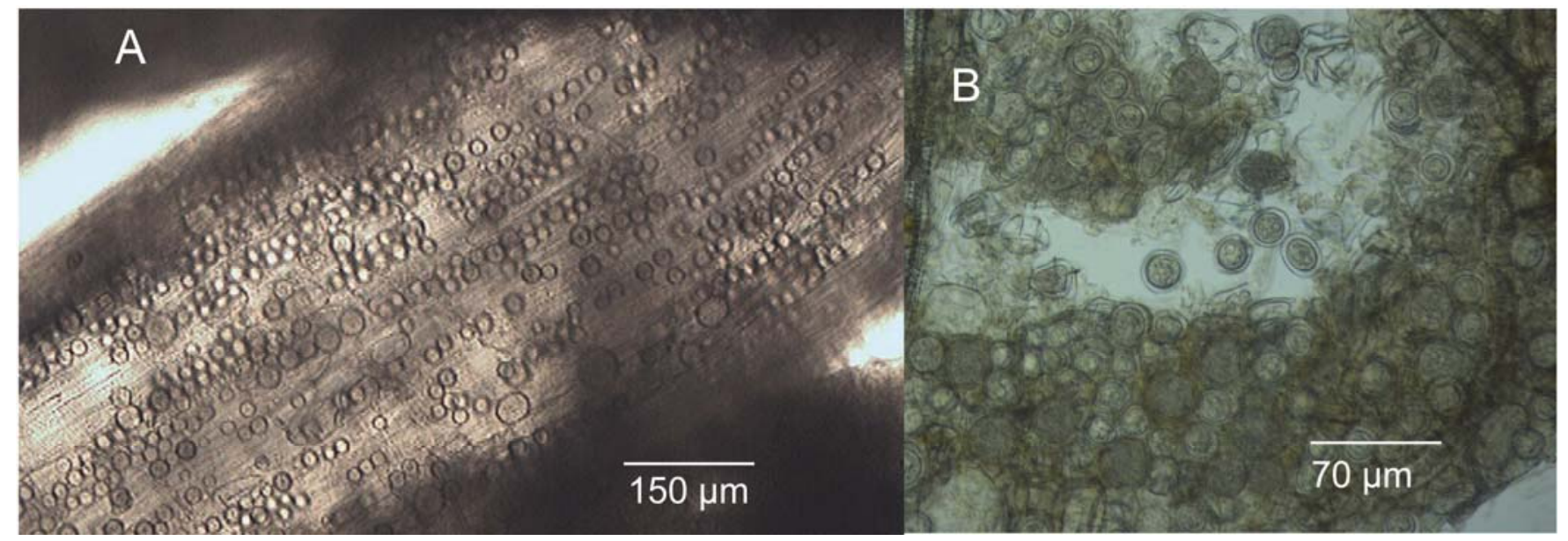

Fig. 4. A, Sporangia and $\mathbf{B}$, resting spores of Olpidium bornovanus in cantaloupe roots 28 days after inoculation. 
root pathogen of melons in the field, as well as its reported relationship to vine decline of melon in the field (8), needs to be clarified.

\section{LITERATURE CITED}

1. Avgelis, A. 1985. Occurrence of melon necrotic spot virus in Crete (Greece). Phytopathol. Z. 14:365-372.

2. Bos, L., Van Dost, H. J. M., Huttigna, H., and Maat, D. Z. 1984. Further characterization of melon necrotic spot virus causing severe disease in glasshouse cucumbers in the Netherlands and its control. Neth. J. Plant Pathol. 90:55-69.

3. Campbell, R. N., and Sim, S. T. 1994. Host specificity and nomenclature of Olpidium bornovanus (=Olpidium radicale) and comparisons to Olpidium brassicae. Can J. Bot. 72:1136-1143.

4. Campbell, R. N., Wipf-Scheibel, C., and Lecoq, H. 1996. Vector-assisted seed transmission of melon necrotic spot virus in melon. Phytopathology 86:1294-1298.

5. Choi, G. S., Kim, J. H., and Kim, J. S. 2003. Characterization of Melon necrotic spot virus isolated from muskmelon. Plant Pathol. J. 19:123-127.

6. Cohen, R., Pivonia, S., Burger, Y., Edelstein, M., Gamliel, A., and Katan, J. 2000. Toward integrated management of Monosporascus wilt of melons in Israel. Plant Dis. 84:496-505.

7. Cuadrado, I. M., Gomez, J., and Moreno, P. 1993. El virus de las manchas necróticas del mélón (MNSV) en Almeŕia. I. Importancia del MNSV como causa de la muerte súbita del melón. Bol. San. Veg. Plagas. 19:93-106.

8. de Cara, M., López, V., Córdoba, M. C., Santos, M., Jordá, C., and Tello, J. C. 2008. Asso- ciation of Olpidium bornovanus and Melon necrotic spot virus with vine decline of melon in Guatemala. Plant Dis. 92:709-713.

9. Gonzales-Garza, R., Gumpf, D. J., Kishaba, A. N., and Bohn, G. W. 1979. Identification, seed transmission, and host range pathogenicity of a California isolate of melon necrotic spot virus. Phytopathology 69:340-345.

10. Grogan, R. G., and Campbell, R. N. 1966. Fungi as vectors and hosts of viruses. Annu. Rev. Phytopathol. 4:29-52.

11. Gu, Q. S., Bao, W. H., Tian, Y. P., Prins, M., Yang, H. X., Lu, J., Liu, L. F., and Peng, B. 2008. Melon necrotic spot virus newly reported in China. Plant Pathol. 57:765.

12. Herrera, J. A., Cebrián, M. C., and Jordá, C. 2006. First report of Melon necrotic spot virus in Panama. Plant Dis. 90:1261.

13. Jordá, C., Font, M. I., Martínez-Culebras, P., and Tello, J. 2005. Viral etiology of diseases detected in melon in Guatemala. Plant Dis. $89: 338$

14. Kishi, K. 1966. Necrotic spot of melon, a new virus disease. Ann. Phytopathol. Soc. Jpn. 32:138-144.

15. Martyn, R. D., and Miller, M. E. 1996. Monosporascus root rot and vine decline: An emerging disease of melons worldwide. Plant Dis. 80:716-725.

16. Morris, T. J., and Dodds, J. A. 1979. Isolation and analysis of double stranded RNA from virus infected plant and fungal tissue. Phytopathology 69:854-858.

17. Sasaya, T., and Koganezawa, H. 2006. Molecular analysis and virus transmission tests place Olpidium virulentus, a vector of Mirafiori lettuce big-vein virus and tobacco stunt virus, as a distinct species rather than a strain of Olpidium brassicae. J. Gen. Plant Pathol. 72:20-25.
18. Stanghellini, M. E., Kim, D. H., Rasmussen, S. L., and Rorabaugh, P. A. 1996. Control of root rot of peppers caused by Phytophthora capsici with a nonionic surfactant. Plant Dis. 80:1113 1116

19. Stanghellini, M. E., Kim, D. H., Waugh, M. M., Ferrin, D. M., Alcantara, T., and Rasmussen, S. L. 2004. Infection and colonization of melon roots by Monosporascus cannonballus in two cropping seasons in Arizona and California. Plant Pathol. 53:54-57.

20. Stanghellini, M. E., Mathews, D. M., and Misaghi, I. J. 2009. Olpidium bornovanus: A root pathogen? (Abstr.) Phytopathology 99:S123.

21. Stanghellini, M. E., Rasmussen, S. L., Kim, D. H., and Rorabaugh, P. A. 1996. Efficacy of nonionic surfactants in the control of zoospore spread of Pythium aphanidermatum in a recirculating hydroponic system. Plant Dis. 80:422-428.

22. Stanghellini, M. E., and Tomlinson, J. A. 1987. Inhibitory and lytic effects of a non-ionic surfactant on various asexual stages in the life cycle of Pythium and Phytophthora species. Phytopathology 77:112-114.

23. Temmink, J. H. M., and Campbell, R. N. 1968 The ultrastructure of Olpidium brassicae. I. Formation of sporangia. Can. J. Bot. 46:951965.

24. Tomassoli, L., and Barba, M. 2000. Occurrence of melon necrotic spot carmovirus in Italy. EPPO Bull. 30:279-280.

25. Tomlinson, J. A., and Thomas, B. J. 1986 Studies on melon necrotic spot virus disease of cucumber and on the control of the fungus vector (Olpidium radicale). Ann. Appl. Biol. 108:71-80.

26. Yakoubi, S., Desbiez, C., Fakhfakh, H., WiptScheibel, C., Marrakchi, M., and Lecoq, H. 2008. First report of Melon necrotic spot virus on melon in Tunisia. Plant Pathol. 57:386. 